\title{
36
}

\section{THAILAND \\ From temples and palaces to modern science communication}

\author{
Ganigar Chen, Wijitra Suriyakul Na Ayudhya \\ and Chanin Suriyakul Na Ayudhya
}

\section{Introduction}

In Thailand, the history of science communication has not been well documented. As in many other countries, science education has been given a high priority by the Thai government with tremendous investment in the national education system. Science is considered to be an important subject at school and for placement exams rather than something that is used in daily life. The notion of communicating science to the general public is not very widespread or something there is public demand for, although there have been efforts by some academics and groups who see its value to society. In recent years, with exchanges and learning with global communities, science communication has become a topic of interest, and more universities and research agencies recognise its importance. This chapter will present the history of science communication in Thailand during the past 150 years in three different sections: from the first record of science communication in Thailand when the Thai monarchy became involved and exerted a strong influence on science; the modern science communication era with the development of science museums and science festivals; and possible trends and developments into the future based on current policy and the national development agenda.

The education system in Thailand began in temples and the royal palace. The temple was a place where all activities take place for Thais from birth till death; it could be considered as the first school in Thailand. The word for science in Thai, vidyasart, was derived from the Sanskrit word meaning 
'knowledge'. The word was used in Thailand to represent modern scientific knowledge stretching back not more than 200 years. Although the idea of science is quite new, Thais have invented and used simple technologies for more than 700 years-technologies such as irrigation systems and rice machines since Sukhothai was the capital city from the year 1430 (although the word 'technology' was first included in the Thai dictionary only in 1982). The first two scientific instruments that came from the Western world were the telescope and the sextant. King Narai the Great had received them as presents from Louis XIV of France in 1685 during the age of the Ancient City, Ayudhaya (1350-1767).

In the 18th century, during the Rattanakosin era, modern science was first introduced to Thailand. The first group of Thai students went to study science in European countries during the reign of King Rama III (1724-1850). However, the first science communication activity recorded in Thailand dates back 150 years to King Mongkut (also known as Rama IV of Thailand, and the fourth king of the Chakri Dynasty from 1782 to the present). The King was a passionate scientist and, in 1866, from his studies in Western and Indian manuscripts in science and astronomy, he calculated when and where a total solar eclipse would occur. He announced and explained the eclipse to the public two years before the event occurred on 18 August 1868 . He encouraged all diplomats and government officers to observe the eclipse at Warkor in the southern part of Thailand. Politically, this strengthened the international reputation of the Siamese King (Science Society of Thailand, 2018b). Because of this, 100 years later, he was honoured as the Father of Science in Thailand.

\section{First record of science communication}

Stories of science and science communication in Thailand started during the reign of King Mongkut, at a time when Thailand was called 'Siam'. Many foreigners may not recognise King Mongkut (Figure 36.1), but they will know the musical play The King and I - the King in this play was based on him. He was one of the great Thai leaders and played an important role in bringing the country out of the political turmoil of colonisation during his rule from 1851 to 1868 through his wisdom and knowledge. 


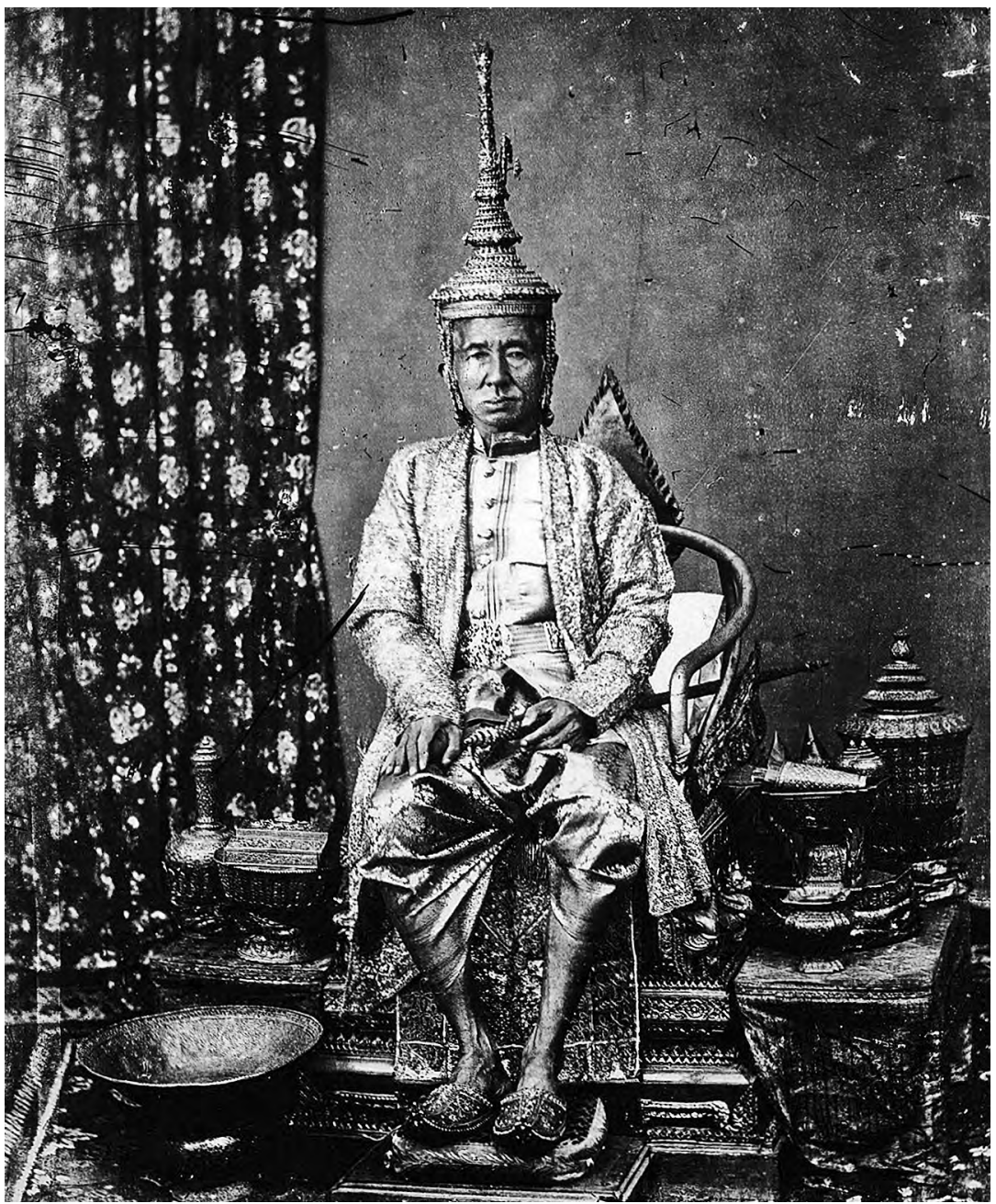

Figure 36.1: King Rama IV (King Mongkut) on his throne, the Father of Science in Thailand.

Source: Science Society of Thailand under the Royal Patronage of His Majesty the King. (c) National Science Museum, Thailand (used with permission).

This was marked as the most important event in Thai history in terms of science, science communication and politics. King Rama IV made other announcements, using the royal bulletin to the public (similar to government newspapers today) to describe astronomical phenomena such as asteroids and comets. People in the old days were afraid of these phenomena and considered them bad luck. The King reassured the people that they were natural events and of no harm, contradicting most myths. These announcements could be considered as first attempts at science communication in Thailand. 
King Rama IV died from malaria not long after the visit to Warkor, but his story and influence did not end then. One hundred years later, on the commemoration of 200 years of Bangkok as the capital city of Thailand, the Science Society of Thailand proposed to the Ministry of Science that the country honour King Rama IV as the Father of Science in Thailand for his knowledge of astronomy, and in leading the nation to be free from colonisation through his outstanding vision and talents in science and politics. Therefore, 18 August, the date that diplomats and royal officers were called to Warkor to observe the full solar eclipse (Figure 36.2), was approved by cabinet as the National Science Day for the modern science community. Warkor has now been developed into a historic science park with science centres and aquariums offered as lifelong learning science centres for schools and the public. Every year in August, National Science Week is celebrated throughout the country in schools, universities and science centres.

King Rama IV brought in and promoted several new technologies during his reign: the printing machine, photography, the automobile and astronomical equipment. Thais became more acquainted to the possibilities these technologies offered, but only small groups of people in the city had the opportunity to use them. Modernisation, in terms of technology, continued during the reign of King Rama V (1868-1910) when royal family members educated in Western countries brought back technologies for national development: the rail system, ships, medicine and architecture. Despite this, very little evidence related to public science communication can be found. After Thailand became democratised in 1932 and during the reign of King Rama IX (King Bhumibol, 1946-2016), science and science communication were again introduced, not for the sake of science but for improving people's lives and well-being in terms of health awareness, agriculture and land use, and environmental improvements.

\section{Modern science communication era in Thailand}

Efforts to communicate science by the scientific community and government bodies began around 1934/35 when a group of science scholars from the Faculty of Arts and Science, Chulalongkorn University (the first university in Thailand), started the first science club or science association. The first chairman of the club was Dr Charoen Thampanich, but it was when Dr Klum Watcharobol, a well-known young scientist who in 1935 had just returned from the United Kingdom, joined Thongsuk Pongsathat (the second chairman) that the science club became more active in science communication 
activities. The aim of the two co-chairs was to ensure scientific activities were made available to the public. The major activity of the club in 1936 was to organise scientific talks by both visiting professors and young scientists, and to promote and sell science books as part of fundraising efforts for the club. Later, the club was handed over from the Faculty of Arts and Science to the Chulalongkorn University Alumni Association. The club continued to organise meetings for members who were mostly scientists and scholars in the university, aiming to exchange ideas, communicate scientific knowledge and organise networking among Thai scientists. A few years later, a formal committee was formed and the club reached an important milestone: the launch the first science magazine in Thailand, the bi-monthly Thailand Science Club Magazine. The magazine covered stories of science both for academics and the public, as well as stories about the university's alumni, faculty and students. The first issue in 1947 is considered the first publication of modern science communication in Thailand. Amazingly, the magazine has continued to be published to this day (Figure 36.3) (Science Society of Thailand, 1998).

Until 27 January 1948, the science club was officially registered as a legal entity under the name Science Society of Siam (SSS), and later became the Science Society of Thailand with open membership. Members included people in science and science educators from universities all over the country, mostly scholars and academics. Membership to the society was open to associate members, science teachers and university students. In 1951, the royal patronage of King Rama IX was granted to the society. Currently there are about 3,000 members nationwide. The society has operated as the backbone of science activities in Thailand, and this year it celebrated its 70th anniversary. The activities of the Science Society of Thailand cover a wide range of areas to promote science to the nation's youth and the public, to strengthen the recognition of scientists and to create a scientific network. Science popularisation activities include issuing monthly science magazines, holding science lecture tours in schools and universities, promoting youth science competitions, sponsoring science radio programs, promoting scientific talent, supporting academic research exchange, encouraging the emergence of new communities of scientific disciplines, empowering science teachers and organising national and international science symposiums and exhibitions.

The Science Society of Thailand is involved in communicating with policymakers to drive science policies important to Thailand. It drives many important science promotion events, including the development of a nationwide youth science project competition with the support of the Ministry of Education and the Ministry of Science and Technology; the initiation of the Science Olympiad of Thailand; and the creation and administration of science recognition awards such as the Annual Thailand Outstanding 
Scientist Award, the Annual Science Teacher Award, and the Outstanding Senior Scientist Award. The keys to the success of the society are its genuine interest in science popularisation and its openness in involving stakeholders. It has been effective in uniting various partners, and this has contributed to a significant and long-term positive impact of science to Thai society. Although the Thai government has now established new agencies to be directly in charge of several science promotion activities, the legacy and the role of the society as a community of people with a common interest in promoting science are still important for the country's science activities.

Around the year 2000, with a national policy that encouraged science and technology, the concept of modern science communication was gradually introduced to Thailand by Thai academics and policy agencies. International experts in science communication were invited to give talks and professional training through university collaborations. Professor Susan Stocklmayer from the Centre for the Public Awareness of Science of The Australian National University and Professor Mike Gore from the Questacon Science and Technology Centre were among the first academics to introduce science communication theory and practice to Thailand through two workshops held at Chulalongkorn University and Khonkaen University. At that time, the training was offered to university academics, teachers and science museum professionals.

In 2005, at a seminar of the 31st Congress on Science and Technology of Thailand organised by the Science Society, the National Science and Technology Development Agency (NSTDA) raised the importance of the role of the media and the engagement of scientists in science communication. NSTDA proposed that in addition to public relations, science communication should be promoted to connect scientists and the public, disseminate scientific and technological knowledge to the people (especially those who lack access to information) and strengthen public understanding of science. NSTDA also proposed drafting a science communication curriculum for science students at university as a long-term partnership project between the Ministry of Education, the Ministry of Science and Technology and the Ministry of Information and Communication Technology, saying it would take 10 years before the curriculum could be implemented. In the meantime, short courses on science communication were planned for journalists and related professions. In 2007, NSTDA opened the Science Media Center as the active body in promoting science communication and bridging scientists, especially in NSTDA, to the public through science talks, media communication and other activities. This enthusiasm for these proposals has encouraged a lot of activities in science communication and inspired a number of people interested in science journalism and informal science 
education to work in different ways to promote science communication. This includes people working for museums and science centres, who later took very active roles in promoting science communication activities and developing science communicators.

Even with the tremendous optimism and enthusiasm shown by various organisations, after almost 20 years a curriculum on science communication is not yet available for a full degree at most universities. In 2014, Srinakharinvirot University announced a master's degree of arts in science and health communication and began the course in 2016. Other universities have started to offer science communication as a three- to six-credit elective in their faculty of science or education or other faculties. Chulalongkorn University, for example, offers science communication in the Faculty of Science, Department of Environment Science; whereas Rajamongkol University offers science communication as an elective for science and education students at its Thanyaburi Campus. Attempts have been made by various universities to open full programs on science communication but there remain two main barriers. Although many universities are interested in offering a science communication degree, the first barriers are regulations set by the Office of Higher Education Commission that require highly qualified professors for a new curriculum or degree. This has delayed attempts to offer this degree and, as of 2020, although many universities have become more interested in science communication, it is still only offered as a three-credit course in either the faculty of education or faculty of science. Other programs more or less cover science communication, including the "Media and Communication Innovation Program" in the Faculty of Education, Kasetsart University, or the "Bachelor of Technology Program in Medical and Science Media" in the Faculty of Medicine, Mahidol University. The second barrier is uncertainty about the work and career path of a science communicator. Where could graduates find employment, and what work would they be doing? At the moment the number of students enrolled even in elective courses is still low. However, most students pursuing a teaching career will be more interested in the subject.

Short courses in science communication seem to be more successful. They are usually organised by institutions rather than universities and run by experts in practice rather than academic institutions due to the lack of professionals in the area. Organisations that are regularly involved in offering such training include NSTDA, the National Science Museum (NSM) and the Science Society of Thailand. Trainers often come from other countries such as the United Kingdom (British Council), Germany (Goethe Institute), Australia (Australian Embassy) or the European Union project on science awareness program. At this moment, we estimate that less than 100 Thai scholars in 
science communication, with degrees from the United Kingdom, France, Australia, New Zealand and the United States, currently work in Thai universities and the Ministry of Science and Technology.

\section{Development of science museums and science centres in Thailand}

The first science museum in Thailand was initiated with the involvement of the Science Society of Thailand. Field Marshal Plaek Phibunsongkhram, then prime minister of Thailand, presided at its opening on 25 June 1954. The museum had a mission to promote science and education for Thai society, and began as a natural history museum where specimens and collections of plants and animals and archives of science books were displayed and stored. In an effort to make it sustainable, the Science Society transferred the operation of the museum to the Faculty of Science, Chulalongkorn University, in 1956. Unfortunately, resourcing continues to be an issue, and although the museum contains a valuable collection of natural science exhibits, the faculty does not have the resources to promote the museum to a wider audience but instead caters more to small groups of visitors (Science Society of Thailand, 1998).

In 1962, the Ministry of Education established the Bangkok Planetarium, the first planetarium in the middle of Bangkok; and in 1975, the Center for Education Museum was established next door. The aim of the Education Museum is to promote lifelong learning through informal experiences, and the exhibition gallery displays a collection of scientific equipment, basic science exhibits and astronomy equipment. In 1992, the Planetarium and the Center for Education Museum were combined and collectively named as the Science Center for Education, operating under the Department of Non-Formal Education in the Ministry of Education. The combined centre focuses on lifelong learning, both non-formal and informal, to serve the people of Thailand. Taking a holistic approach to learning, the centre focuses on science, technology, natural science, environmental science and astronomy. Many scientists have shared their experiences of visiting the planetarium and the centre when they were young, and how this inspired them to pursue their careers in science. Until now, more than 15 small science centres for education had been developed in Thai provinces. These provincial science centres play important supportive roles to local schools, providing extra-curricular experiences in science and extra classrooms for students in the non-formal education system. 
In 1995, the NSM was established by the Ministry of Science and Technology. The organisation is a state enterprise with the mission to promote public awareness of science through exhibitions, research and collections. NSM's mission focuses more on science for the public and the relevance of science to daily life for the development of the nation. NSM operates a series of science and science-related museums, including the National Science Museum (shown in Figure 36.4), the Natural History Museum, the Information Technology Museum and the Rama IX Ecology and Environment Museum. The National Science Museum has become a key player to connect various research and science agencies under the Ministry of Science and Technology as well as other ministries, universities and societies to drive science popularisation and science communication in Thailand.

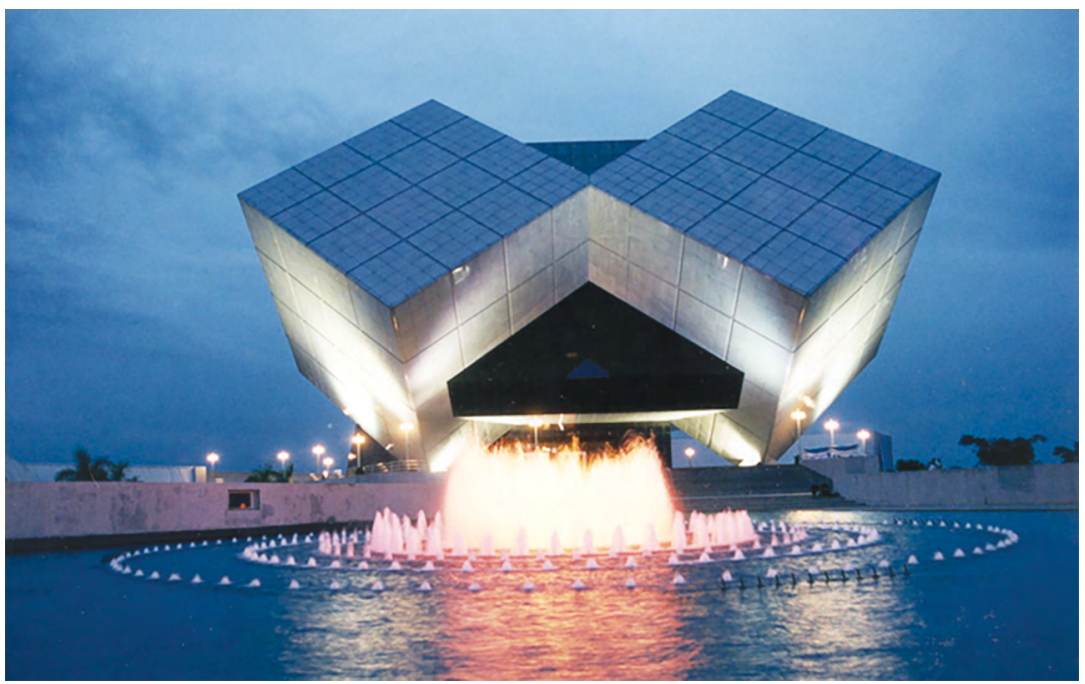

Figure 36.2: Night view of the iconic cube building of the National Science Museum, located in Pathum Thani province, $40 \mathrm{~km}$ north of Bangkok, which was opened to the public in 2000 . The building was especially designed to present a new image of a modern science museum.

Source: Science Society of Thailand under the Royal Patronage of His Majesty the King. (C) National Science Museum, Thailand (used with permission).

This became the turning point, allowing science communication in Thailand to leap ahead. NSM provides many attractive channels of science communication to communicate science to the public, such as interactive exhibitions, science activities, shows and dramas, laboratory programs and walk rallies (see Figures 36.5 and 36.6). 
Even though science communication centres in Thailand have been well spread geographically, many people in the countryside cannot access these essential facilities and tools due to travel limitations. It is difficult for people from remote areas to get to the museums. Therefore, in 2002, the National Science Museum decided to launch the Science Caravan Project. It includes interactive exhibitions, activities, games, shows, laboratories and fun activities for children. Moreover, in some places, the caravan offers a science camp, science training workshops, and teacher-training programs. By using various types and styles of science communication at the same time and place at the caravan site, information can be relayed to a wider target audience. This project is one of the most effective ways to communicate science to people in rural areas and around the country.

NSM promotes science communication and trains science communicators in Thailand by providing a number of workshops to researchers, educators, museum staff and students. It also organises contests and competitions on science communication, such as drama contests, film contests, writing contests and university student programs in science communication. The Young Thai Science Ambassadors program has been continuously carried out since 2004 and this is considered a prestigious program that has inspired and created a network of young science communicators in Thailand.

\section{Science festivals in Thailand}

The first science festival in Thailand was initiated with the aim of promoting science popularisation and scientific culture. In 1968, on the 100th anniversary of King Rama IV's Solar Eclipse Event, the Science Society of Thailand started a large-scale public science event with new technology and modern displays. This was organised at the Science Center for Education and presided over by His Majesty King Bhumibol (King Rama IX). This festival also provided communication between Warkor and Bangkok to emphasise the connection of this special event with the important historical astronomical phenomenon.

In 1982, the Thai government accepted a recommendation from the Science Society to set 18 August - the day of the eclipse predicted by King Rama IV_-as National Science Day. The first science festival in 1982 had all sorts of activities to commemorate the 'Father of Science': the opening ceremony, the presentation of an award for outstanding scientists and science teachers, the Talents in Science program, a science exhibition by various science agencies, science project competitions and science lectures. The event was well-covered by the media in both Thai and English. The success of the first festival has led to sponsorship and support from the private sector to fund awards for youth 
science programs. In 1983, the Minister of Science, Technology and Energy joined the National Science Day event and saw it as a good opportunity to promote science to the public. He appointed the Ministry of Science to extend the event from one day to a week (National Science Week, 18-24 August), made it an annual event and allocated a budget so that the activity could be more widely implemented (Chen, 2014).

In 1997, the event moved to the Sirikit Convention Center, where it could accommodate more people and, for the first time, activities were organised in 23 provinces nationwide. This has significantly changed the atmosphere of science popularisation in Thailand and increased our ability to reach a wider audience. Since 1982, August has become the month of science both for academics and the public. The Ministry of Education, through the Science Society of Thailand, supports universities to organise youth science activities during Science Week, while the Ministry of Science and Technology provides additional funding to approximately 18 major universities to assist in the organisation of an open house for local science events under the national theme. All science education centres, science research agencies and faculties of science in universities have become the central points in organising science events during the week. Science Week activities are also implemented in schools throughout the country.

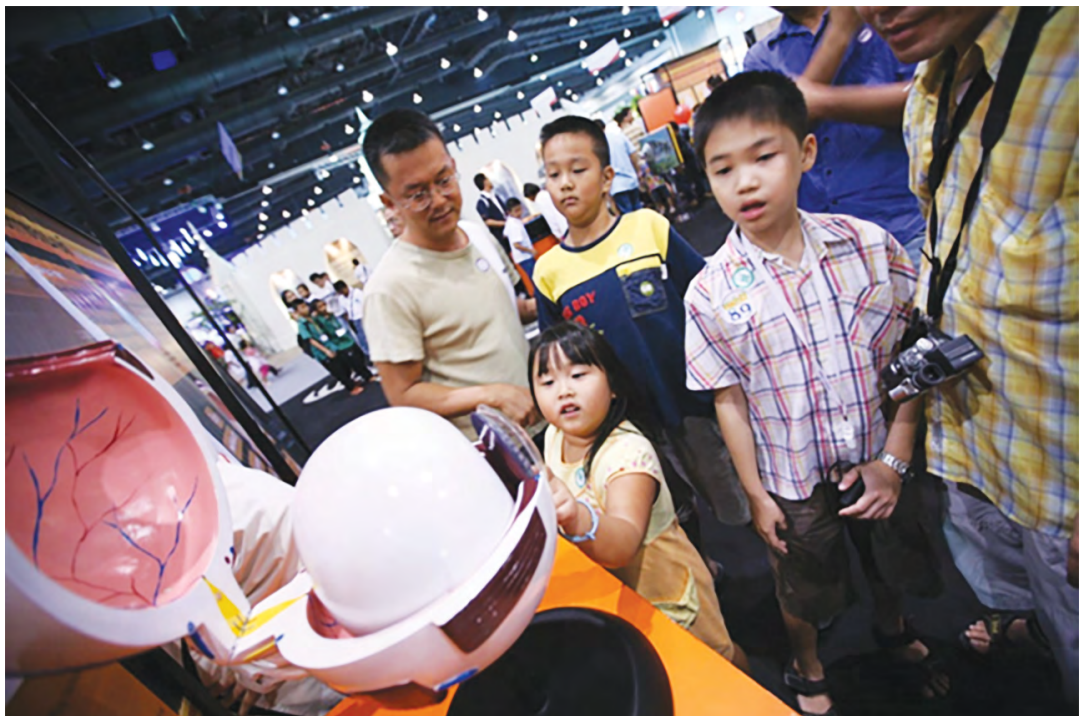

Figure 36.3: The National Science and Technology Fair, the largest public science event organised annually every August.

Source: Science Society of Thailand under the Royal Patronage of His Majesty the King. (c) National Science Museum, Thailand (used with permission). 
In 2008, the Ministry of Science and Technology appointed the National Science Museum to organise the National Science and Technology Fair, a mega-size science festival (40,000 square metres) in the Central region. It had cutting-edge technology and thematic exhibitions relevant to global issues such as climate change, energy, environment and health (Figure 36.8). The festival included international participants organised through embassies and has been recognised as a flagship project in science popularisation. In 2018, the Ministry of Science and Technology decided to promote science to support its initiatives in creating innovation. This was known as the Thailand 4.0 policy in creating innovation, and it was given a special budget to organise further mega-scale science festivals in four other locations outside Bangkok, at Chiangmai, Khon Kaen, Songkhla and especially Warkor, where the big celebration returned Thai science graciously to its origin. The science festival has reached more than 1.5 million people nationwide and is organised by the Ministry of Science and Technology and the Ministry of Education (National Science Museum, 2018).

\section{Policy and future of public science communication in Thailand}

In early 2000, the NSTDA with the National Statistical Office funded a study on public attitudes towards science and technology. The results were published in 2006 and, to no one's surprise, television was the most influential and effective mode in communicating science to the public. According to the report, only 20 per cent of survey participants could name a Thai scientist (National Statistical Office, 2006). Another study, by Hathayatham (2005), reported that most Thais could only name the past two kings of Thailand (King Bhumibol and King Mongkut) as scientists. This reflected the limited interest of the public in scientific research and the lack public information about Thai scientists. However, while most Thais still consider science and technology to be important to themselves and the country, pursuing a science career is not promoted or encouraged by parents for their children.

The NSTDA also funded a study conducted by a team from the Science Society of Thailand to evaluate science promotion activities and develop a national policy proposal on science awareness. The study concluded that in the past 20 years, most science activities were intended to promote public understanding and interest in science, with less effort placed on long-term human resource development in science and technology (Mongkolkul, 2006). The report proposed guidelines for enhancing public awareness of science as follows: 
1. Target: more scientific activities should be planned to engage youths 18 years and older, people from medium-income families, and policymakers.

2. Tools: various tools in science popularisation should be employed such as print media and mass media, science museums and science festivals during the National Science Week, national science awards, national youth science awards, public science in science curricula, and 'scientists meet policymakers' sessions.

3. Infrastructure: basic infrastructure to help with the popularisation of science needs to be established. This includes the development of science communicators, creation of science media centres, engagement of science associations, and funding for science awareness on research and development.

4. Policy: to ensure the successful implementation of these guidelines, the government should support a system to include science awareness policies, the restructuring of management or responsible agencies, and budget allocation. In addition, science literacy surveys should be conducted on a regular basis to monitor change and set future directions.

At the same time as the study (and for the first time) the Ministry of Science and Technology included a strategy on 'promoting public awareness of science' as one of the key five strategies for the ministry's action plan for 2004-13 (National Science and Technology Development Agency, 2004). The strategy set goals to enhance public awareness and understanding about science and technology, ensure public use of science in daily life, and provide access to science learning resources in local communities. There were four measures under this strategy: to enhance learning and creativity among youths and the public; to promote the engagement of scientists and policymakers in communicating science; to develop more learning centres and resources in science; and to increase public access to science news and information.

After several governmental restructures, the National Science Technology and Innovation Policy Office (STI) became the key player in developing the national strategy. Science awareness and science communication were considered to be of less priority and mentioned only as a part of the action plan. The National Science Technology and Innovation Policy and Plan for 2012-21 places more emphasis on increasing competitiveness through research and development, preparing for change due to globalisation, supporting social equality and security through investment in science infrastructure and research funding, and developing human resources. 
Science awareness and communication fall under human resource development but were given a lower priority than formal education or workforce capacity building (National Science Technology and Innovation Policy Office, 2012). Regardless of all the established policies, a recent report by the Organisation for Economic Co-operation and Development (OECD) still ranked science literacy in Thailand to be below the OECD average. The report blamed this on the quality of science education offered in schools and the limited availability of qualified science teachers in rural or difficult areas. With regards to government policy in promoting science, since 2015 the government has pushed forward the policy of Thailand 4.0 to advance the nation through science, technology and innovation. This has driven a demand for educational reform and the active participation of science agencies, as well as increased involvement by the private sector to promote science and science education. To date, there are science schools, special science classrooms and scholarships available. Informal science education and science communication, which at one point were considered trivial, are now more in demand, and agencies from both private and public sectors are moving in this direction and developing more programs to accommodate the demand.

An example is the International Science Film Festival launched in 2004 as a cooperative effort by the Goethe Institute with the Institute for the Promotion of Teaching Science and Technology, the NSM, and several universities and science centres. The operation extended to provincial schools and universities and had reached out to 600,000 students in 2017.

During the past decade, it has been encouraging to see many research agencies becoming more interested and involved in science awareness and science communication. There are fewer than 15 agencies under the Ministry of Science and Technology, more than half of which have recently established their own awareness program units. These include agencies such as the Geo-Informatics and Space Technology Development Agency, the National Science and Technology Development Agency, the National Astronomical Research Institute of Thailand and the National Science and Technology Policy Office. The National Science Museum has played a major role on behalf of the Ministry of Science and Technology as the national platform in coordinating all agencies within the Ministry of Science and Technology, as well as cross-ministries to organise national science communication and science popularisation programs all year round. These programs include the National Science and Technology Fair that reaches out to approximately 1 million people annually, science caravans and science and technology competitions. 
A recent policy of the Ministry of Science and Technology encourages the engagement of young scientists in public science communication, especially those who had received national scholarships and are working in rural areas.

The National Science Technology and Innovation Policy Office provides funding to awareness programs from various agencies, to prototype science communication models adopted from the United Kingdom, the United States and Australia based on their international experience, models such as FameLab (Figure 36.9), SchoolLab, Maker Space, Science Idol, Science Ambassadors and others. These programs promote scientists in science communication and empower future scientists with communication skills.

Getting scientists involved in these programs is difficult. A report by Chen in 2017 revealed barriers to the engagement of scientists in science communication, including policy, time, confidence and skill. The government has to make tremendous efforts to encourage young scientists to contribute to science communication, but these efforts are unlikely to be successful unless the barriers are unlocked systematically.

In addition to agencies related to science and technology, communication of science and environment issues has been carried out extensively by other ministries: the Ministry of Education works to promote science, technology, engineering and mathematics (STEM) learning and STEM careers; the Ministry of Natural Resources and Environment publicises issues of biodiversity and environmental protection; the Ministry of Public Health and the Ministry of Energy work in the areas of their responsibility. Numerous universities have started to encourage their researchers to be more engaged in science, and medical universities, such as Mahidol University, have launched online and science channels on cable television for the public.

The employment of professionals or trained science communicators is still in its early stage in Thailand. The role and importance of being a science communicator is unclear due to the lack of understanding of the profession. Most people working in the field are involved in public relations, as scientists or educators, as shown in Figure 36.10. Very few agencies are aware of this profession and the differences between being science communicators and science educators. 


\section{Science communication in the future}

Due to the government's strong will to promote science, technological research and industry, on 2 May 2019, the Department of Higher Education merged with the Ministry of Science and Technology, giving birth to a new ministry called the Ministry of Higher Education, Science, Research and Innovation. This signalled the national need to strengthen and integrate research units both in academic and other public sectors. The growing number of science and technology-related agencies provides a signal that science communicators will be in demand. While the infrastructure to produce more science communicators domestically is still questionable, there are scholarships for Thai students returning from abroad (for example, from the United Kingdom and Australia), who are trained and ready to kick off the professional development of science communicators. The group of students who returned between 2001 and 2018 could be the hope for the future of science communication in Thailand.

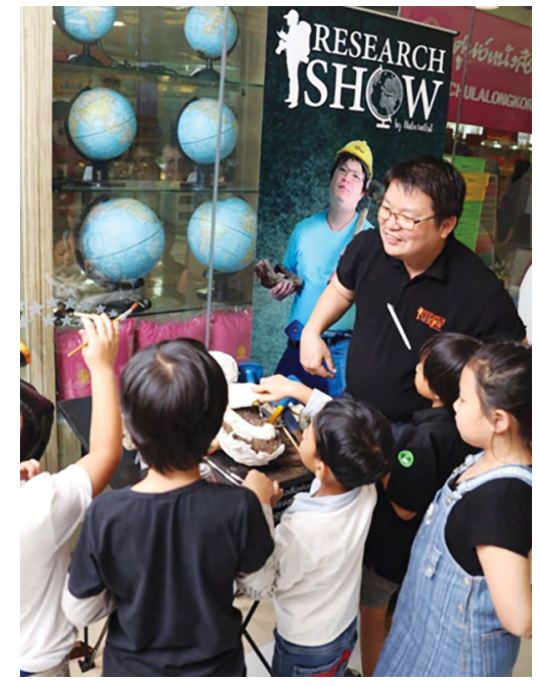

Figure 36.4: Research show by a naturalist, one of the most popular programs of the National Science Museum where scientists of the museum communicate science to the public.

Source: Science Society of Thailand under the Royal Patronage of His Majesty the King. (C) National Science Museum, Thailand (used with permission).
Since the government's policy in 2018 was aimed at promoting science and innovation to raise the competitiveness of the nation, high levels of investment have been made into building new science research facilities and industrial incubators. The government has invested more on learning resources such as museums, learning centres and online media. It seems inevitable that science communication will be in greater demand in the future.

Although science activities have been promoted in the past 10 years, it was obvious that the biggest effort was still focused on student engagement. To really reach out to the general public, increased effort, better techniques and more resources will be required in order to be successful. Five barriers have been identified: 
1. The public perception of science is that science is not for adults. Some people find science difficult but others recognise the importance of science, especially for students to study in schools and get high grades in examinations so they can have good future careers.

2. In order to communicate science to adults in a stimulating and interesting manner, it is important to gain knowledge from scientists themselves as they are aware of interesting scientific facts and evidence. Scientists from universities or research institutes can share their knowledge by storytelling to science journalists, the media and museums, which makes it critical to involve scientists in science communication.

3. Thailand needs more science communicators and better-trained science communicators if it is to make science interesting to the public. This can be a weakness and an opportunity at the same time. Currently, it is obvious that there are not enough well-trained science communicators due to the non-availability of study programs at both undergraduate and graduate levels in Thai universities. Therefore, the attempts made by research agencies to communicate science have been ineffective. As the need of science communicators increases, this will provide capacity building and career opportunities in this area.

4. Science communication at the national and organisational levels is still not strongly encouraged. In Thailand, even though the government is generous in terms of providing adequate budgets and investing in infrastructure, various research organisations should allow their scientists to be more freely engaged and involved in public science communication. In countries such as China and Korea, the policy on science communication is strongly supported as part of a national strategy of promoting scientific innovation in a technology-based society. In China, science popularisation is identified to have the same priority as research support.

5. There is limited involvement of journalists and public media in science communication. Journalists do not feel that there is enough support from the scientific community. The lack of cooperation or communication with scientists and the limited scientific information that is generally available make it difficult for journalists and the media to present scientific information of enough interest to attract public attention. Moreover, the high cost and complicated production of scientific content has discouraged the media from getting involved in science communication.

Despite all the barriers, the future of science communication in Thailand looks promising. Due to future changes in technology, society and environment, it is likely that science communication will become an emerging topic of interest. Possibilities include having online platforms to communicate science 
as well as having decentralised or localised science communication modes. This will ensure that the majority of Thais would have access to science on demand, especially scientific information pertinent to their everyday lives. In order to make science more relevant and valuable, and to move the nation forward through science, technology and innovation, Thailand needs to create an ecosystem with the involvement of all stakeholders, so that science is integrated in people's lives.

\section{References}

Chen, G. (2014). National Science Festival of Thailand: Historical roots, current activities and future plans of the National Science Fair. Journal of Science Communication, 13(4). doi.org/10.22323/2.13040304.

Chen, G. (2017). Approach in Engaging Scientist in Science Communication. Paper Presentation on Academic Forum 'Dual Upgrading of Theory and Practice in Science Communication', Beijing, China.

Chen, G. (2018). Engaging scientists in science communication (poster). Public Communication of Science and Technology Conference. Dunedin, New Zealand.

Hathayatham, A. (2005). The Public Awareness of Science in Thailand: A Case Study in Biotechnology ( $\mathrm{PhD}$ thesis). The Australian National University.

Mongkolkul, K. (2006). Promoting Public Awareness of Science and Technology for the Thai Society. Bangkok: National Strategy, National Science and Technology Development Agency.

National Science Museum (2018). National Science Museum Annual Report 2018, Thailand. Retrieved from www.nsm.or.th/images/Annual_Report_2018.pdf.

National Science and Technology Development Agency (2004). National Strategy in Science and Technology 2004-2013. Bangkok.

National Science Technology and Innovation Policy Office (2012). Science, Technology, and Innovation Plan 2012-2021. Bangkok.

National Statistical Office, National Science and Technology Development Agency $\&$ Science and Technology Awareness Subcommittee. (2006). Youth Interest in Science and Technology Report Year 2006.

Office of Science Technology and Innovation Policy. (2012). Science Technology Innovation Policy and Plan I:2012-2021. 1st edition. Bangkok, Thailand: Office of Science Technology and Innovation Policy.

Science Society of Thailand. (1998). 50 Years Science Society of Thailand under Royal Patronage of His Majesty The King. Bangkok, Thailand. 
Science Society of Thailand. (2018a). 70 Years Science Society of Thailand under Royal Patronage of His Majesty The King. Bangkok, Thailand.

Science Society of Thailand. (2018b). Warkor: Past-present-future. Bangkok, Thailand.

\section{Timeline}

\begin{tabular}{|c|c|c|c|}
\hline Event & Name & Date & Comment \\
\hline $\begin{array}{l}\text { First interactive science } \\
\text { centre established. }\end{array}$ & $\begin{array}{l}\text { The Center for } \\
\text { Education Museum }\end{array}$ & 1975 & $\begin{array}{l}\text { 1992: name was changed } \\
\text { to Science Center for } \\
\text { Education }\end{array}$ \\
\hline $\begin{array}{l}\text { First national (or large } \\
\text { regional) science festival. }\end{array}$ & $\begin{array}{l}\text { Science festival, } \\
\text { organised at the } \\
\text { Science Centre } \\
\text { for Education and } \\
\text { presided over by } \\
\text { His Majesty King } \\
\text { Bhumibol }\end{array}$ & 1968 & $\begin{array}{l}\text { National Science Day } \\
\text { established } 18 \text { August } \\
1982 \text { and celebrated with } \\
\text { festival }\end{array}$ \\
\hline $\begin{array}{l}\text { An association of science } \\
\text { writers or journalists } \\
\text { or communicators } \\
\text { established. }\end{array}$ & & 1947 & \\
\hline $\begin{array}{l}\text { First university courses } \\
\text { to train science } \\
\text { communicators. }\end{array}$ & $\begin{array}{l}\text { Master's degree of } \\
\text { arts in science and } \\
\text { health communication } \\
\text { at Srinakharinvirot } \\
\text { University }\end{array}$ & 2016 & $\begin{array}{l}\text { Short courses offered by } \\
\text { institutions rather than } \\
\text { universities are more } \\
\text { successful }\end{array}$ \\
\hline $\begin{array}{l}\text { First national } \\
\text { conference in science } \\
\text { communication. }\end{array}$ & $\begin{array}{l}\text { Science } \\
\text { communication } \\
\text { workshops }\end{array}$ & 2000 & $\begin{array}{l}\text { 2008: Hhosted the ASPAC } \\
\text { (Asia Pacific Network of } \\
\text { Science and Technology } \\
\text { Centres) conference }\end{array}$ \\
\hline $\begin{array}{l}\text { National government } \\
\text { program to support } \\
\text { science communication } \\
\text { established. }\end{array}$ & $\begin{array}{l}\text { The National Science } \\
\text { Museum Project }\end{array}$ & 2000 & \\
\hline $\begin{array}{l}\text { First significant initiative } \\
\text { or report on science } \\
\text { communication. }\end{array}$ & $\begin{array}{l}\text { National policy on } \\
\text { the development of } \\
\text { public awareness of } \\
\text { science and lifelong } \\
\text { learning. }\end{array}$ & 2006 & $\begin{array}{l}\text { While there has not been } \\
\text { a report specifically on } \\
\text { science communication, } \\
\text { the } 2006 \text { report did refer } \\
\text { to these matters }\end{array}$ \\
\hline $\begin{array}{l}\text { National Science Week } \\
\text { founded. }\end{array}$ & $\begin{array}{l}\text { National Science } \\
\text { Week celebrated } \\
\text { with festival, lectures, } \\
\text { exhibitions }\end{array}$ & $\begin{array}{l}18 \\
\text { August } \\
1982\end{array}$ & $\begin{array}{l}\text { National Science Day } \\
\text { was established in 1982, } \\
\text { and was extended to a } \\
\text { National Science Week } \\
\text { in } 1983\end{array}$ \\
\hline $\begin{array}{l}\text { A journal completely or } \\
\text { substantially devoted to } \\
\text { science communication } \\
\text { established. }\end{array}$ & $\begin{array}{l}\text { Science, a monthly } \\
\text { journal established } \\
\text { by the Science } \\
\text { Society of Thailand }\end{array}$ & 1948 & $\begin{array}{l}\text { Science communicated } \\
\text { news, information and } \\
\text { events to the public and } \\
\text { members of the Science } \\
\text { Society }\end{array}$ \\
\hline
\end{tabular}




\begin{tabular}{|l|l|l|l|}
\hline Event & Name & Date & Comment \\
\hline $\begin{array}{l}\text { First significant radio } \\
\text { programs on science. }\end{array}$ & $\begin{array}{l}\text { Science Society of } \\
\text { Siam (later Science } \\
\text { Society of Thailand) } \\
\text { established a science } \\
\text { radio program }\end{array}$ & 1950 & $\begin{array}{l}\text { This program was } \\
\text { produced as a talk with } \\
\text { questions. The first few } \\
\text { stories related to oil, } \\
\text { scientific disciplines, } \\
\text { seasons in Thailand, etc. }\end{array}$ \\
\hline $\begin{array}{l}\text { First significant TV } \\
\text { programs on science. }\end{array}$ & $\begin{array}{l}\text { Asset of the Land } \\
\text { was the first science } \\
\text { film produced by the } \\
\text { Science Society of } \\
\text { Thailand }\end{array}$ & 1960 & $\begin{array}{l}\text { It was screened in a movie } \\
\text { theatre }\end{array}$ \\
\hline $\begin{array}{l}\text { First awards for scientists } \\
\text { or journalists or others for } \\
\text { science communication. }\end{array}$ & $\begin{array}{l}\text { The first award } \\
\text { for scientists was } \\
\text { announced on } \\
\text { the first national } \\
\text { science day }\end{array}$ & 18 & $\begin{array}{l}\text { August } \\
1982\end{array}$ \\
\hline Other significant events. & $\begin{array}{l}\text { The first Science } \\
\text { Lecture Tour in 1965 }\end{array}$ & 1965 & \\
\hline
\end{tabular}

\section{Contributors}

Ganigar Chen is vice president of the National Science Museum (NSM), Thailand.

Dr Wijitra Suriyakul Na Ayudhya is the director of Research Division, Information Technology Museum (ITM) at the National Science Museum (NSM), Thailand.

Chanin Suriyakul Na Ayudhya is the head of the Science Communication Division at the National Science Museum (NSM), Thailand. 
This text is taken from Communicating Science: A Global Perspective, edited by Toss Gascoigne, Bernard Schiele, Joan Leach, Michelle Riedlinger, Bruce V. Lewenstein, Luisa Massarani and Peter Broks, published 2020 by ANU Press, The Australian National University, Canberra, Australia.

doi.org/10.22459/CS.2020.36 